\title{
The Importance of Image Guidance during Epidural Injections: Rates of Incorrect Needle Placement during Non-Image Guided Epidural Injections
}

\section{Joshua H. Levin ${ }^{1 *}$, Ryan Wetzel ${ }^{2}$ and Matthew W. Smuck ${ }^{3}$}

${ }^{1}$ Aurora Advanced Healthcare, Milwaukee, WI, USA

${ }^{2}$ Midlands Orthopaedics, Columbia, SC, USA

${ }^{3}$ Department of Orthopaedic Surgery, Stanford University, Redwood City, CA, USA

\begin{abstract}
Background: Epidural steroid injections are commonly-performed procedures used to treat several spinal conditions. Traditionally, these procedures have been performed without image guidance. However, a large number of blindly-performed injections are inaccurate with needle placement outside the epidural space. The purpose of the current article was to review the data on inaccuracy rates of non-image guided epidural injections.
\end{abstract}

Results and Conclusions: $9-52 \%$ of non-image guided caudal epidural injections are outside the epidural space. $7-30 \%$ on non-image guided lumbar interlaminar epidural injections is outside the epidural space.

Keywords: Epidural; Fluoroscopy; Accuracy; Caudal; Interlaminar

\section{Introduction}

Epidural corticosteroid injections have become increasingly popular in the treatment of radiculopathy and discogenic pain [1]. These injections can be performed via one of three routes for accessing the epidural space-caudal, interlaminar, or transforaminal. In the caudal approach, a needle is inserted through the sacral hiatus into the posterior epidural space. In the interlaminar approach, a needle is inserted between two adjacent laminae, through the ligamentum flavum, and into the posterior epidural space. This is typically done in the midline or just off the midline. In the transforaminal approach, a needle is inserted along an oblique path, through the foramen, into the epidural space. Using this approach, the anterior epidural space can be accessed. Historically, interlaminar and caudal epidural injections have been performed without the use of image guidance and contrast dye injection to confirm needle placement, while fluoroscopy or CT guidance with contrast confirmation is typically used when the transforaminal approach is applied. A criticism of blind (non-image guided) injections is the lack of confirmation that the needle is in fact properly placed in the epidural space with optimal contrast flow, and that medication is therefore delivered to the intended target. Without accurate needle placement and ideal contrast flow, outcomes would be expected to suffer, both in clinical practice and in research studies. In fact, this has been demonstrated in a randomized controlled trial [2]. The purpose of the current article is to review the literature on blind epidural injections in order to determine the inaccuracy rates of these injections.

\section{Methods}

Extensive Medline/Pubmed searches were performed using the limits "human" and "English" without date limitations. Under these limits, each of the following terms was searched: blind epidural injection, non image epidural, fluoroscopy epidural, fluoroscopy spine, and epidural accuracy. All resulting articles were dated between December 1967 and August 2011. This search resulted in 2102 citations (some of which were repeats) which were reviewed. Additionally, the reference section from each relevant article was reviewed in order to find additional appropriate articles. One article that appeared at first to meet the criteria for inclusion was excluded since contrast dye was not used to confirm epidural needle placement [3].

\section{Background}

In each of the studies listed below, a physician attempted to place a needle in the epidural space without image guidance. After the physician believed that the needle was in the epidural space, contrast dye was injected under fluoroscopic guidance to determine if the needle was in fact in the epidural space. Inaccuracy rates refer to the percentage of injections that were not in the epidural space. Details about the procedures, including patient positioning, needle size, technique used, specialty and experience of the performing physician, and complications are included if they were reported in the studies.

\section{Results}

\section{Caudal injections}

The inaccuracy rates of caudal epidural injections ranged from 9-52\% [4-10]. If the rates of intravascular injections are included in the inaccuracy rates, the lower end of the range is increased to $23 \%$ [9]. See Table 1 for further details.

\section{Interlaminar Injections}

The inaccuracy rates of lumbar interlaminar epidural injections ranged from $7-30 \%[4,8,10-12]$. See Table 2 for further details.

\section{Discussion}

The older literature on epidural corticosteroid injections demonstrated mixed results. Given the high inaccuracy rates of nonimage guided injections, it is not surprising that many of the early studies on epidural corticosteroid injections failed to demonstrate efficacy. One major flaw in the studies is the lack of image guidance in all randomized controlled trials prior to the year 2000. The current review article demonstrates that $9-52 \%$ of blind caudal epidural injections and $7-30 \%$ of blind interlaminar epidural injections are outside the epidural

*Corresponding author: Joshua $\mathrm{H}$. Levin, Aurora Advanced Healthcare Milwaukee, WI, USA, Tel: 804-301-0866; Fax: 262-532-1554; E-mail: joshualevin49@hotmail.com

Received November 25, 2011; Accepted February 17, 2012; Published February 20, 2012

Citation: Levin JH, Wetzel R, Smuck MW (2012) The Importance of Image Guidance during Epidural Injections: Rates of Incorrect Needle Placement during Non-Image Guided Epidural Injections. J Spine 1:113. doi:10.4172/21657939.1000113

Copyright: $\odot 2012$ Levin JH, et al. This is an open-access article distributed under the terms of the Creative Commons Attribution License, which permits unrestricted use, distribution, and reproduction in any medium, provided the original author and source are credited. 
Citation: Levin JH, Wetzel R, Smuck MW (2012) The Importance of Image Guidance during Epidural Injections: Rates of Incorrect Needle Placement during Non-Image Guided Epidural Injections. J Spine 1:113. doi:10.4172/2165-7939.1000113

Page 2 of 3

\begin{tabular}{|c|c|c|c|c|c|c|c|}
\hline & $\begin{array}{l}\% \text { of injections } \\
\text { outside the epidural } \\
\text { space }\end{array}$ & $\begin{array}{l}\text { Percent } \\
\text { intravascular }\end{array}$ & $\begin{array}{l}\text { Number of } \\
\text { patients }\end{array}$ & Needle & $\begin{array}{l}\text { Patient } \\
\text { position }\end{array}$ & Specialty of physician & Comments \\
\hline Manchikanti et al. [9] & $9 \%$ & $\begin{array}{l}14 \% \text { (additional to } \\
\text { the } 9 \% \text { ) }\end{array}$ & 100 & 20G Tuohy & Prone & Anesthesiologist & $\begin{array}{l}\text { Ventral filling in } 69 \% \text {. } \\
\text { Appropriate nerve root filling in } 43 \% \text {. }\end{array}$ \\
\hline White et al. [4] & $25 \%$ & $6.4 \%$ & $\begin{array}{l}\text { ? (less than } \\
304)\end{array}$ & $22 \mathrm{G}$ & $?$ & $\begin{array}{l}\text { Anesthesiologist and } \\
\text { orthopedist }\end{array}$ & \\
\hline Stitz et al. [7] & $26 \%$ & $3.7 \%$ & 54 & 20G beveled & Prone & Physiatrist & $\begin{array}{l}\text { Improved accuracy with easily identified } \\
\text { anatomic landmarks. }\end{array}$ \\
\hline Barham et al. [10] & $26 \%$ & $1.5 \%$ & 137 & $22 \mathrm{G}$ & Prone & $\begin{array}{l}\text { Spine surgeons, } \\
\text { associate specialist, } \\
\text { specialist registrars }\end{array}$ & $\begin{array}{l}\text { No difference between the different } \\
\text { levels of training of the practitioners }\end{array}$ \\
\hline Lewis et al. [6] & $27 \%$ & $?$ & 26 & $21 G$ & Prone & ?Anesthesiologist & $\begin{array}{l}\text { All inaccurate injections had a negative } \\
\text { or indeterminate "whoosh" test. }\end{array}$ \\
\hline Price et al. [8] & $36 \%$ & $5 \%$ & 100 & $\begin{array}{l}18 \mathrm{G} 2 \text { " straight } \\
\text { bevel }\end{array}$ & $\begin{array}{l}\text { Prone or } \\
\text { lateral }\end{array}$ & Anesthesiologists & $\begin{array}{l}\text { Outside the epidural space in } 15 \% \text { that } \\
\text { were thought to be definitely accurate. }\end{array}$ \\
\hline Renfrew et al. [5] & $\begin{array}{l}38 \% \text { (experienced) } \\
52 \% \text { (inexperienced) }\end{array}$ & $9.2 \%$ & 316 & $?$ & Prone & $\begin{array}{l}\text { Radiologist (residents, } \\
\text { fellows, and } \\
\text { attendings) }\end{array}$ & $\begin{array}{l}\text { Outside the epidural space in } 22 \% \\
\text { of "easy" patients and in } 15 \% \text { when } \\
\text { confident that it was accurate. }\end{array}$ \\
\hline
\end{tabular}

Table 1: Summary of caudal epidural injections.

\begin{tabular}{|c|c|c|c|c|c|c|c|c|}
\hline & $\begin{array}{l}\text { \% of injections outside } \\
\text { the epidural space }\end{array}$ & $\begin{array}{l}\text { Percent } \\
\text { intravascular }\end{array}$ & $\begin{array}{l}\text { Number of } \\
\text { patients }\end{array}$ & Needle & $\begin{array}{l}\text { Patient } \\
\text { position }\end{array}$ & Technique & Specialty of physician & Comments \\
\hline Price et al. [8] & $7 \%$ & $0 \%$ & 100 & 16G Tuohy & $\begin{array}{l}\text { Seated or } \\
\text { lateral }\end{array}$ & $\begin{array}{l}\text { LOR to air or } \\
\text { saline }\end{array}$ & Anesthesiologists & $\begin{array}{l}\text { Significantly more accurate } \\
\text { than the caudal route. }\end{array}$ \\
\hline $\begin{array}{l}\text { Fredman et al. } \\
{[12]}\end{array}$ & $8 \%$ & $?$ & 50 & $\begin{array}{l}\text { 18G Tuohy w/ } \\
\text { epidural catheter }\end{array}$ & Lateral & LOR to air & ?Anesthesiologist & $\begin{array}{l}47 \% \text { entered at the intended } \\
\text { level. } \\
26 \% \text { had contrast dye reach } \\
\text { the site of pathology. } \\
3 \text { dural punctures. } \\
1 \text { inadvertent myelogram. }\end{array}$ \\
\hline Liu et al. [20] & $8 \%$ & $?$ & 100 & 20G Tuohy & $\begin{array}{l}\text { Seated or } \\
\text { lateral }\end{array}$ & LOR to saline & $\begin{array}{l}\text { Pain management fellows, } \\
\text { anesthesiology residents }\end{array}$ & $\begin{array}{l}\text { Less accurate in male } \\
\text { patients and in patients over } \\
70 \text { years old. }\end{array}$ \\
\hline $\begin{array}{l}\text { Mehta et al. } \\
{[11]}\end{array}$ & $17 \%$ & $?$ & 100 & Tuohy & $?$ & $\begin{array}{l}\text { LOR to air or } \\
\text { saline }\end{array}$ & Anesthesiologists & \\
\hline White et al. [4] & $30 \%$ & $0 \%$ & $\begin{array}{l}? \text { (less } \\
\text { than 304) }\end{array}$ & 18G Crawford & $?$ & $?$ & $\begin{array}{l}\text { Anesthesiologist and } \\
\text { orthopedist }\end{array}$ & 2 dural punctures \\
\hline
\end{tabular}

LOR $=$ loss of resistance

Table 2: Summary of interlaminar epidural injections.

space when confirmed with fluoroscopy and contrast injection. The inaccuracy rate is even higher when one includes the injections found with fluoroscopy to be intravascular, despite having negative flashback or aspiration. One can reasonably assume that if the needle is not correctly placed within the epidural space, then the corticosteroid is not being delivered to the site of pathology, and that the patient is in essence receiving a placebo injection, or at best a systemic corticosteroid treatment - which has been shown in 3 randomized placebo-controlled trials to be no more effective than placebo for the treatment of lumbar radicular pain [13-15].

Often times, without considering the information presented in the current article, physicians or insurance carriers report inefficacy from epidural corticosteroid injections based mostly on the mixed results of the early studies. In fact, a recent review article included non-image guided interlaminar and caudal epidural corticosteroid injection studies along with fluoroscopically guided transforaminal epidural corticosteroid injection studies under the assumption that all epidural corticosteroid injections are equal [16]. Given the high inaccuracy rate of blind epidural injections detailed above, and the superior results of fluoroscopically guided transforaminal corticosteroid injections over blind interlaminar corticosteroid injections [2], such an assumption is not valid.

Another tool that is sometimes used during the performance of epidural injections is CT guidance. Although one would expect higher accuracy when using this technique compared to blind injections, we are not aware of any studies that have investigated this topic. Additionally, we are not aware of any studies that have evaluated the comparative efficacy of CT guided injections to blind injections or fluoroscopically guided injections.

Regarding the comparative accuracy between the caudal and interlaminar epidural injection techniques, two studies addressed this issue. White et al. [4] found no difference between the two approaches, whereas Price et al. [8] demonstrated significantly better accuracy with the interlaminar approach ( $7 \%$ inaccuracy rate vs. $36 \%$ inaccuracy rate, $\mathrm{p}<0.001)$.

Since the vast majority of studies were performed by anesthesiologists, a comparison of inaccuracy rates between medical specialties cannot be made. The one study by a physiatrist demonstrated a $26 \%$ inaccuracy rate during caudal injections [7], and the one study by radiologists demonstrated a $38-52 \%$ inaccuracy rate during caudal injections [5]. The one study that included injections performed by an orthopedist demonstrated a $25 \%$ inaccuracy rate during caudal injections and a $30 \%$ inaccuracy rate during interlaminar injections [4], and the one study by spine surgeons and associate specialists or specialist registrars demonstrated a $26 \%$ inaccuracy rate [10].

The current review article only included studies of injections that were originally performed without image guidance, before confirming placement with fluoroscopy and contrast dye injection. The reasoning 
behind this was to closer emulate actual practice in which fluoroscopy either is or is not used, and to be able to make a comparison between blind injections and those done with fluoroscopic guidance with contrast dye confirmation. Three additional studies about inaccuracy rates of epidural injections were not included in the current article because they used intermittent fluoroscopy to guide needle placement. In these studies, after the needle was thought to be accurately placed in the epidural space, contrast dye was injected to confirm the needle placement. After injection of contrast to confirm needle placement, one might expect a higher accuracy rate from these studies since they used fluoroscopy for needle placement. Surprisingly, this was not the case. In the first study, Stojanovic et al. [17] evaluated 38 cervical interlaminar epidural injections performed by resident, fellow, and experienced attending physicians. Patients were placed in the prone position and a 22-gauge Tuohy needle was inserted with the guidance of intermittent AP fluoroscopic images. The loss of resistance to air technique was used. When the needle was believed to be in the epidural space, contrast dye was injected and multiple fluoroscopic views were obtained to determine if the needle placement was accurate. Surprisingly, despite fluoroscopic guidance for needle placement in addition to using the loss of resistance to air technique, the inaccuracy rate was $53 \%$. Unilateral epidural spread occurred $51 \%$ of the time, and ventral epidural spread occurred just $28 \%$ of the time. Level of training of the physician was not a statistically significant predictor of accuracy. In the second study, Bartynski et al. [18] evaluated 74 lumbar interlaminar epidural injections performed by an experienced neuroradiologist. A 20-gauge Tuohy needle was advanced using the loss or resistance to air technique with the guidance of AP, lateral, and oblique fluoroscopic views. After loss of resistance was encountered, contrast dye was injected. Again, despite the use of fluoroscopy, there was a $26 \%$ inaccuracy rate demonstrated after injection of contrast dye. There were no complications. In the third study, Alemo et al. [19] evaluated 371 lumbar interlaminar epidural injections. An 18 gauge Tuohy needle was advanced using the loss of resistance technique with AP and lateral fluoroscopic guidance. The inaccuracy rate in this study was $12 \%$.

\section{Conclusions}

9-52\% of non-image guided caudal epidural injections are outside the epidural space. When intravascular injections are included in the analysis, the inaccuracy rate is even higher. $7-30 \%$ of non-image guided lumbar interlaminar epidural injections are outside the epidural space. $53 \%$ of fluoroscopically guided interlaminar cervical epidural injections that are done without contrast dye confirmation are outside the epidural space.

Patients undergoing epidural corticosteroid injections without image guidance should be informed that approximately one quarter to one third of caudal injections, and approximately $10-30 \%$ of lumbar interlaminar injections, result in needle placement outside the epidural space. Additionally, they should be informed that fluoroscopically guided interlaminar epidural injections that are performed without the use of contrast dye confirmation may result in needle placement outside the epidural space in approximately $25 \%$ of lumbar, and $50 \%$ of cervical epidural injections.

\section{References}

1. Friedly J, Chan L, Deyo R (2007) Increases in lumbosacral injections in the Medicare population: 1994 to 2001. Spine (Phila Pa 1976) 32: 1754-1760.

2. Thomas E, Cyteval C, Abiad L, Picot MC, Taourel P, et al. (2003) Efficacy of transforaminal versus interspinous corticosteroid injectionin discal radiculalgia - a prospective, randomised, double-blind study. Clin Rheumatol 22: 299-304.

3. Eastwood D, Williams C, Buchan I (1998) Caudal epidurals: the whoosh test. Anaesthesia 53: 305-307.

4. White AH, Derby R, Wynne G (1980) Epidural injections for the diagnosis and treatment of low-back pain. Spine (Phila Pa 1976) 5: 78-86.

5. Renfrew DL, Moore TE, Kathol MH, el-Khoury GY, Lemke JH, et al. (1991) Correct placement of epidural steroid injections: fluoroscopic guidance and contrast administration. AJNR Am J Neuroradiol 12: 1003-1007.

6. Lewis MP, Thomas P, Wilson LF, Mulholland RC (1992) The 'whoosh' test. A clinical test to confirm correct needle placement in caudal epidural injections. Anaesthesia 47: 57-58.

7. Stitz MY, Sommer HM (1999) Accuracy of blind versus fluoroscopically guided caudal epidural injection. Spine (Phila Pa 1976) 24: 1371-1376.

8. Price CM, Rogers PD, Prosser AS, Arden NK (2000) Comparison of the cauda and lumbar approaches to the epidural space. Ann Rheum Dis 59: 879-882.

9. Manchikanti L, Cash KA, Pampati V, Damron KS, McManus CD (2004) Evaluation of lumbar transforaminal epidural injections with needle placement and contrast flow patterns: a prospective, descriptive report. Pain Physician 7: 217-223.

10. Barham G, Hilton A (2010) Caudal epidurals: the accuracy of blind needle placement and the value of a confirmatory epidurogram. Eur Spine J 19: 14791483.

11. Mehta M, Salmon N (1985) Extradural block. Confirmation of the injection site by X-ray monitoring. Anaesthesia 40: 1009-1012.

12. Fredman B, Nun MB, Zohar E, Iraqi G, Shapiro M, et al. (1999) Epidural steroids for treating "failed back surgery syndrome": is fluoroscopy really necessary? Anesth Analg 88: 367-372.

13. Friedman BW, Esses D, Solorzano C, Choi HK, Cole M, et al. (2008) A randomized placebo-controlled trial of single-dose IM corticosteroid for radicular low back pain. Spine (Phila Pa 1976) 33: E624-629.

14. Finckh A, Zufferey $P$, Schurch MA, Balagué $F$, Waldburger M, et al. (2006) Short-term efficacy of intravenous pulse glucocorticoids in acute discogenic sciatica. A randomized controlled trial. Spine (Phila Pa 1976) 31: 377-381.

15. Ghahreman A, Ferch R, Bogduk N (2010) The efficacy of transforaminal injection of steroids for the treatment of lumbar radicular pain. Pain Med 11 : 1149-1168.

16. Armon C, Argoff CE, Samuels J, Backonja MM (2007) Assessment: use of epidural steroid injections to treat radicular lumbosacral pain: report of the Therapeutics and Technology Assessment Subcommittee of the American Academy of Neurology. Neurology 68: 723-729.

17. Stojanovic MP, Vu TN, Caneris O, Slezak J, Cohen SP, et al. (2002) The role of fluoroscopy in cervical epidural steroid injections: an analysis of contrast dispersal patterns. Spine (Phila Pa 1976) 27: 509-514.

18. Bartynski WS, Grahovac SZ, Rothfus WE (2005) Incorrect needle position during lumbar epidural steroid administration: inaccuracy of loss of air pressure resistance and requirement of fluoroscopy and epidurography during needle insertion. AJNR Am J Neuroradiol 26: 502-505.

19. Alemo S, Sayadipour A (2010) Observational study of the use of an epidurogram in interlaminar lumbar epidural steroid injection. $\mathrm{Br} \mathrm{J}$ Anaesth 104: 665-666.

20. Liu SS, Melmed AP, Klos JW, Innis CA (2001) Prospective experience with 20-gauge Tuohy needle for lumbar epidural steroid injections: Is confirmation with fluoroscopy necessary? Reg Anesth Pain Med 26: 143-146. 